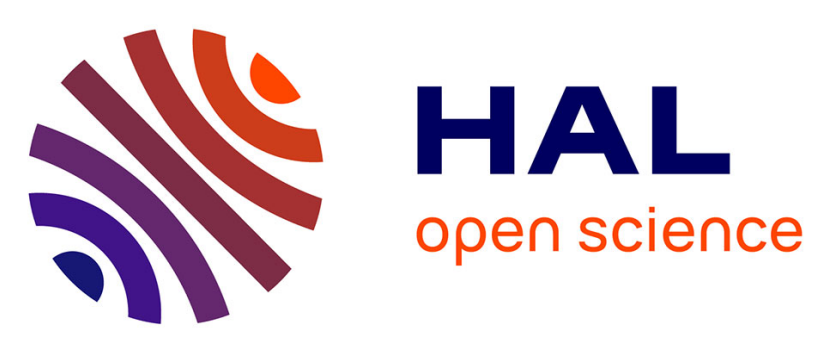

\title{
Relevance of inverse method to characterize structure borne noise sources: application on an industrial case and comparison with a direct method
}

Aurélien Cloix, Jean-Luc Wojtowickiw

\section{- To cite this version:}

Aurélien Cloix, Jean-Luc Wojtowickiw. Relevance of inverse method to characterize structure borne noise sources: application on an industrial case and comparison with a direct method. CFM 2015 22ème Congrès Français de Mécanique, Aug 2015, Lyon, France. hal-03446495

\section{HAL Id: hal-03446495 \\ https://hal.science/hal-03446495}

Submitted on 24 Nov 2021

HAL is a multi-disciplinary open access archive for the deposit and dissemination of scientific research documents, whether they are published or not. The documents may come from teaching and research institutions in France or abroad, or from public or private research centers.
L'archive ouverte pluridisciplinaire HAL, est destinée au dépôt et à la diffusion de documents scientifiques de niveau recherche, publiés ou non, émanant des établissements d'enseignement et de recherche français ou étrangers, des laboratoires publics ou privés. 


\title{
Relevance of inverse method to characterize
} structure borne noise sources: application on an industrial case and comparison with a direct method

\author{
A. CLOIX ${ }^{\text {a }}$ J-L. WOJTOWICKI ${ }^{\mathrm{a}}$ \\ a. Vibratec, 28 chemin du petit bois, 69130 Ecully, France.
}

\section{Résumé :}

Le présent papier s'appuie sur le travail réalisé au sein du projet de recherche collaboratif TESSA («Transfert des Efforts des Sources Solidiennes Actives »). L'une des tâches rattachées au projet TESSA consiste à caractériser la variabilité de mesures inter-laboratoires des forces de blocage sur une pompe à eau de moteur thermique. Ce papier décrit uniquement les mesures réalisées au sein du laboratoire Vibratec. Deux méthodes de mesure des efforts de blocage ont été mises en œuvre : une mesure directe, à l'aide de capteurs d'efforts, faisant l'objet des mesures inter-laboratoire, ainsi que l'application d'une méthode inverse ne nécessitant pas d'utiliser de capteurs d'effort. Des tests de répétabilité et de reproductibilité ont été réalisés afin de quantifier les écarts de mesures au sein d'un même laboratoire en vue de l'analyse de la dispersion inter-laboratoire. Des montages répondants aux spécificités de chacune des deux méthodes ont été conçus : bloc très rigide en aluminium pour la méthode directe et un support dédié à la méthode inverse, avec notamment un fort recouvrement et amortissement modal dans la bande de fréquence d'intérêt. La comparaison des résultats obtenus par les deux méthodes montre que la méthode inverse est acceptable pour mesurer des efforts de blocage sur un banc «non rigide » et qu'il est ainsi envisageable de l'appliquer « in-situ », avec la source dans son environnement de fonctionnement réel.

\begin{abstract}
:
The current paper is based on the French research program TESSA ("Transfert des Efforts des Sources Solidiennes Actives"). A specific task within TESSA project consists in the characterization of the measurements variability between several laboratories, of the blocked forces on a water pump of a heat engine. This paper focuses only on the measurements carried out at Vibratec laboratory. Two kinds of measurements have been carried out: direct measurements, using force sensors, which is the target of the inter-laboratory measurements, and an inverse method without force sensor requirements. Reproducibility and repeatability tests have been done in order to quantify the measurement variability within the same laboratory, in preparation for the inter-laboratory disparity analysis. Specific supports have been designed for each method: a rigid aluminum block for the direct method and a support dedicated to the inverse method, including a high modal density and modal damping in the frequency range of interest. The comparison of both methods shows that the inverse method is satisfying for the measurement of blocked forces on a "non-rigid" support and that it is possible to apply such methodology "in-situ", with the source in its real environment.
\end{abstract}

\section{Mots clefs : Source solidienne, Effort de blocage, Méthode inverse}




\section{Introduction}

The current paper is based on the French research program TESSA ("Transfert des Efforts des Sources Solidiennes Actives"). The aim of this project is the control of the vibratory sources inside vehicles (cars and trucks). New technologies inside vehicles (arrival of electrical and hybrid engines on the market, driving assistance and comfort enhancement...) increases the number of vibratory and acoustic sources. In order to respect the manufacturers' specifications, equipment suppliers must know and control the excitations, especially the dynamic forces, caused by their systems. This paper focuses on the characterization of the blocked forces at attachment points of a water pump of an engine power unit. Two kinds of measurements have been carried out: direct measurements, using force sensors, and an inverse method. Reproducibility and repeatability tests have been done. The measurement campaign is presented in this document.

\section{Water pump description}

The water pump is connected at 3 points: uncoupled connection with soft mounts at each point. A specific water closed-circuit has been designed specifically for the study (water tank, hoses,...).

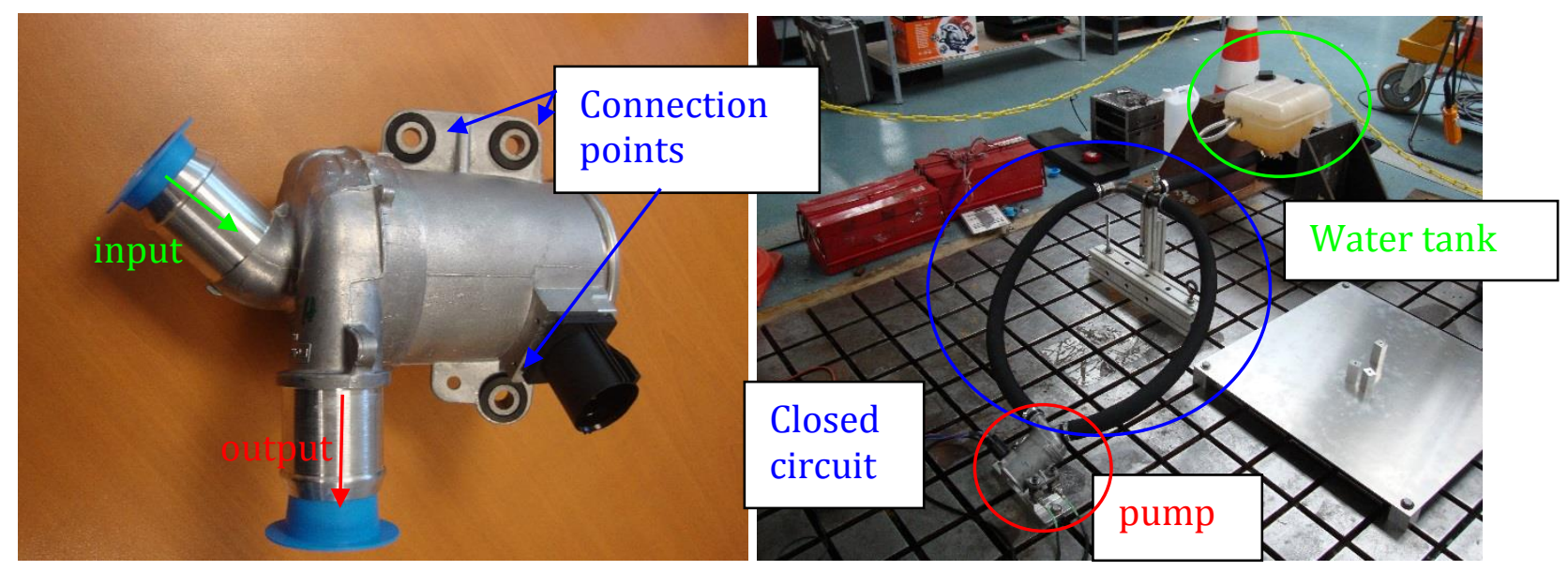

A) Water pump - top view

B) B) Blocked forces measurements - test bench overview

\section{Direct measurements}

Blocked forces are measured on test bench, using tri-axial force sensors at connection points, between the pump and mechanical interface (pump support). Two kinds of pump supports have been designed and tested:

- First support, used for measurements in all the laboratories,

- An aluminium block, used only by Vibratec.

The force sensors are located between the pump and the support. In order to measure the blocked forces, it is necessary to have a sufficiently rigid bench, compared to the dynamic stiffness of the source, at connection points. The dynamic stiffness ratio between the support and the pump has to be large enough, all over the frequency range of interest. The two supports are characterized, in terms of dynamic stiffness at connection points, compared with each other and with the dynamic stiffness of the pump mounts. Difference between the two supports are observed. The modal response of the support influences the measurements with the first supports, for frequencies above $1 \mathrm{KHz}$. 

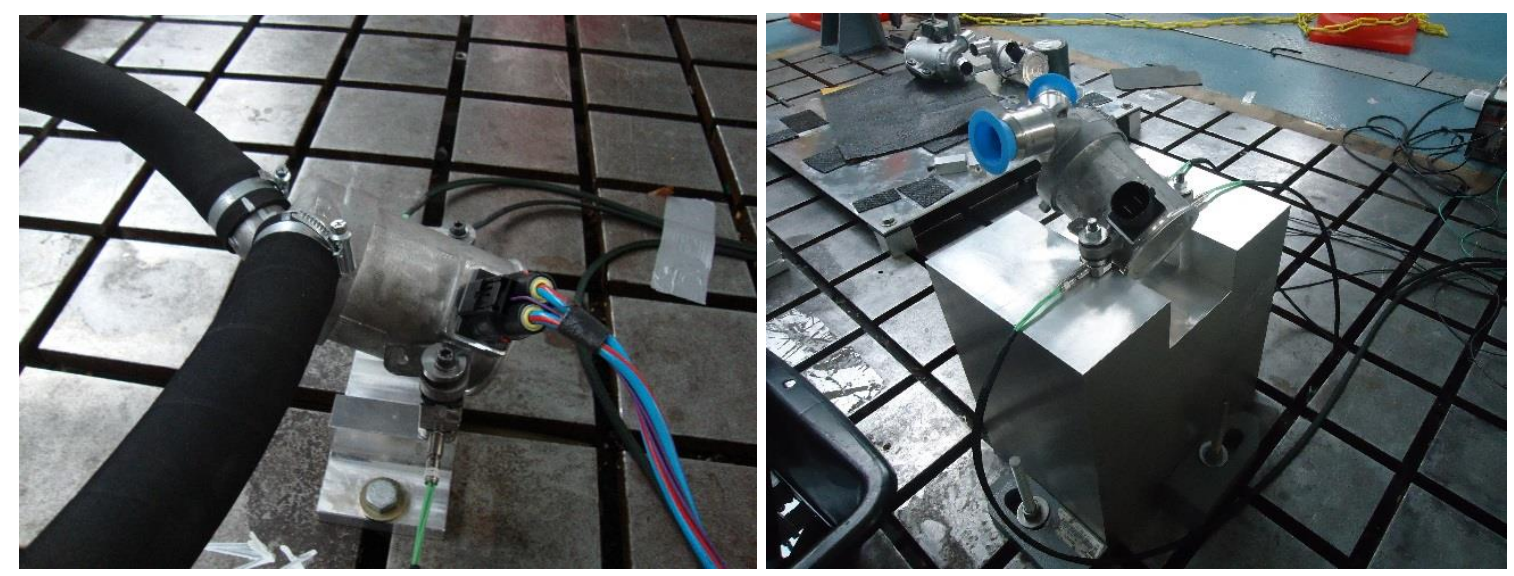

A) Water pump on inter-laboratory support.

B) Water pump on aluminium block

During the data acquisition, the pump temperature and current consumption are measured.

To improve the accuracy of inter-laboratory results analysis, repeatability (consecutive runs, without removing sensors) and reproducibility tests are carried out ( $1^{\text {st }}$ step: tightening / loosening of pump screws $-2^{\text {nd }}$ step: assembly / disassembly of the whole test bench).

\section{Inverse method}

The blocked forces are estimated using an inverse method [1]. A specific support (aluminium plate and beams interfaces) which meets the requirements of such approach has been designed:

- High modal density in the frequency range of interest,

- $\quad$ Addition of damping material on the plate (high modal damping).
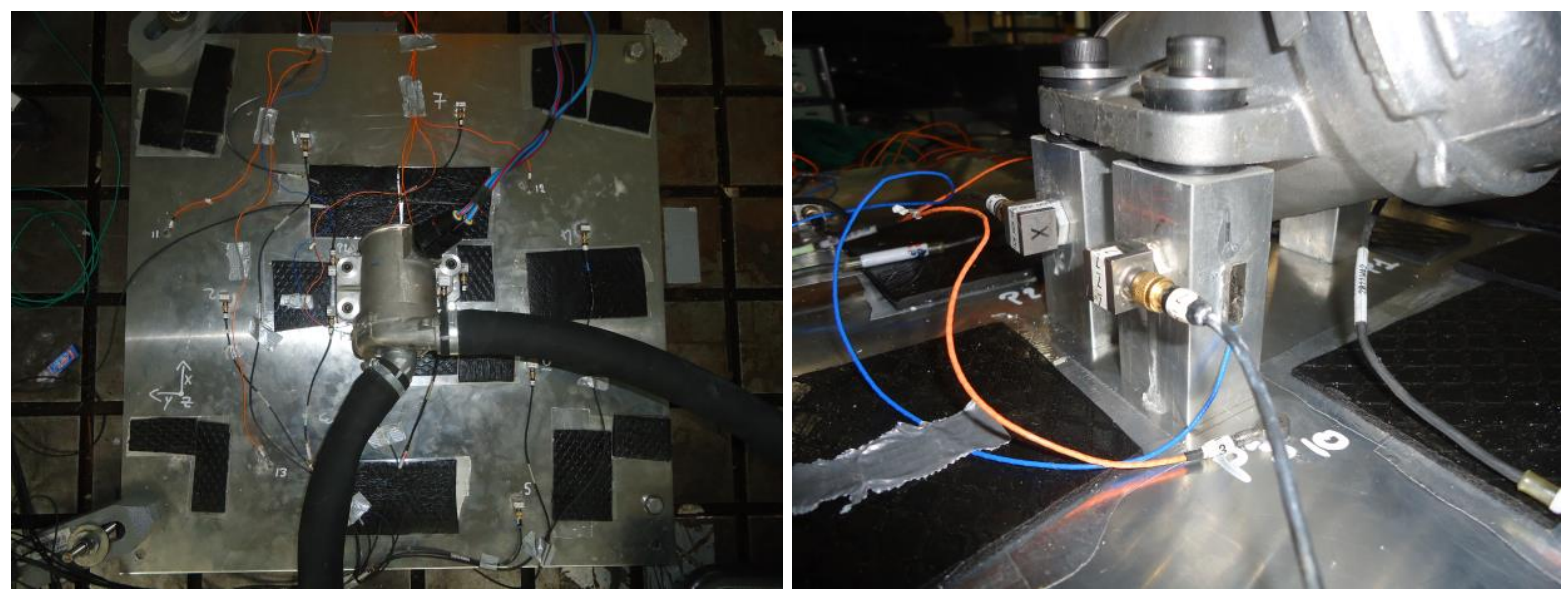

A) Aluminium plate with indicators and target sensors

B) Pump beam supports

Two steps are needed to estimate the blocked forces using an inverse method:

- Static measurements: characterisation of the transfer functions acceleration over force on indicators and targets points. Excitations are applied with an impact hammer, as close as possible to the real pump forces application. The accelerometers (indicators and targets) are distributed on the aluminium plate and on the beam supports. The transfer functions are measured with the source on the support, in order to estimate the blocked forces. 
- Operating conditions: accelerations on indicators and targets points are measured in operating conditions (pump running at constant speed: $4800 \mathrm{rpm}$ ).

Improvement of the inverse method accuracy: The condition number of the transfer functions matrix has been reduced by choosing an optimal transfer function data set (choice of indicators) and by reducing close force inputs to an equivalent force tensor on a virtual point. The accuracy of the inverse method results is validated by comparing acceleration levels measured and computed on the target points. These points are only used for validation, they are not used for the forces computations.
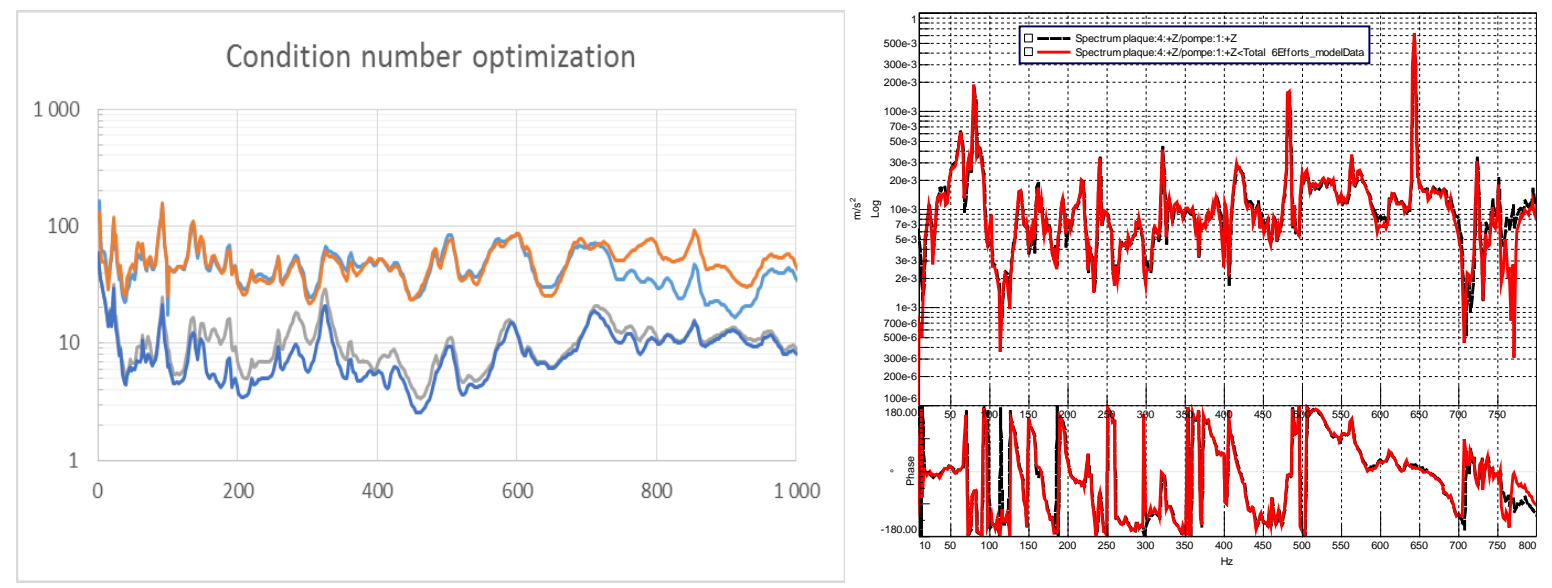

A) Condition number optimization

B) Acceleration level on target points - Measured - Computed

\section{$4 \quad$ Results analysis}

\subsection{Reproductibility}

A detailed analysis of the measurements, DOF by DOF, for each acquisition, remains very sensitive. Therefore a global criteria is used: For each harmonic (from H1 to H8), the quadratic sum of the forces on all DOF is computed. These RMS values are then compared, for each harmonic, for all the acquisitions, including the reproducibility and repeatability tests (Two kinds of supports for direct measurements \& inverse method).

Measurements show difficulty to measure in the same configurations: Assembly and disassembly of the whole bench cause high variability on the blocked forces, even with a global criteria. A strict control of the pump behavior is necessary (control of the current consumption for example). Moreover, tests have shown a temperature dependency, especially on the first harmonic. Highest is the temperature, highest is the force level at connection points.

\subsection{Direct and inverse methods comparison}

The blocked forces measured using an inverse method are compared to the blocked forces measured on the aluminum block. The blocked forces measured on the first support (direct method) are not taken into account for this comparison, due to the dynamic stiffness condition which is not fulfilled on the 
whole frequency range of interest: The dynamic stiffness of this support decreases due to its modal behavior.

The inverse method - subject to a meticulous implementation which meets the requirements of such methodology - gives similar results than direct measurements (same order of magnitude):

- Using a support with enough modal density and high modal damping, in the frequency range of interest, in order to improve the dependency of the equations of the system to be solved,

- Choosing indicator points which give an optimal condition number of the transfer functions matrix,

- During static test, impacting hammer forces as close as possible to the real force location,

- If necessary, reducing close inputs to an equivalent force tensor on a virtual point,

- Keeping the same instrumentation between static and operational measurements (do not remove the sensors).

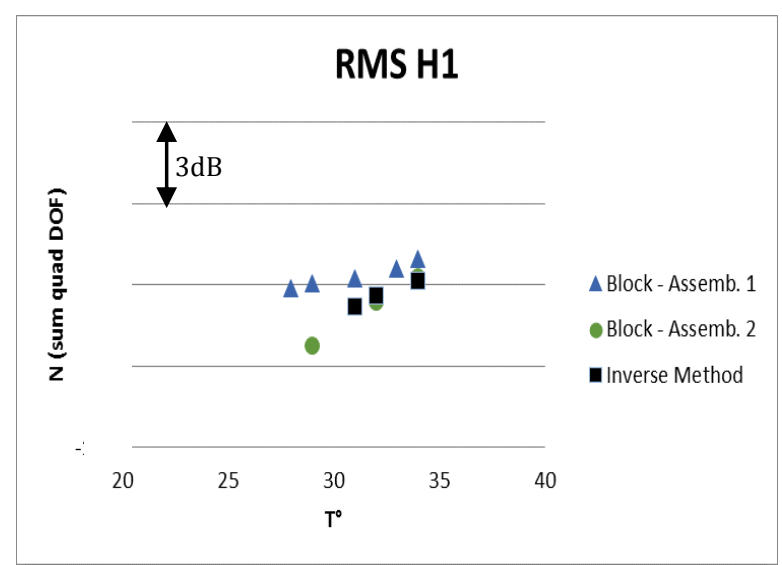

Comparison of global RMS level on first harmonic, versus temperature $-\mathrm{dB}$ ref $1 \mathrm{~N}$

\section{Conclusion}

The main conclusion of this study is that direct and inverse methods can lead to the same results under some conditions. The first obvious but necessary condition is that both methods must be strictly applied in respect with their own assumptions. The second condition is that there is no point in comparing each DOF individually. A wise global criteria, such as a global RMS level on all DOF, gives a better comparison.

\section{Références}

[1] P. Bouvet, C. Braguy, P. Gauch, Applications industrielles des méthodes inverses pour caractériser les sources mécaniques et acoustiques, SIA 2004 «Le Diesel : aujourd'hui et demain » 